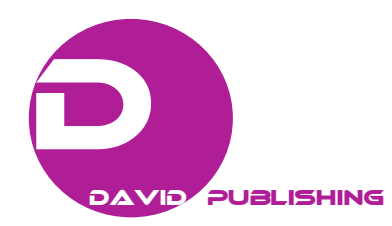

\title{
Efficiency of Combined Solar Thermal Heat Pump Systems
}

\author{
Werner Lerch, Andreas Heinz, Richard Heimrath and Christoph Hochenauer \\ Institute of Thermal Engineering, Graz University of Technology, Graz 8010, Austria
}

\begin{abstract}
In this project, different combinations of solar energy and heat pump systems for preparation of DHW (domestic hot water) and space heating of buildings are analyzed through dynamic system simulations in TRNSYS (Transient System Simulation Program). In such systems, solar thermal energy can be used, on one hand, directly to charge the buffer storage and, on the other hand, as heat source for the evaporator of the HP (heat pump). In this work systems, in which solar heat is only used directly (parallel operation of solar and HP), systems using the collectors also as a heat source for the HP are analyzed and compared to conventional air HP systems. With a combined parallel solar thermal HP system, the system performance compared to a conventional HP system can be significantly increased. Unglazed selectively coated collectors as source for the HP have the advantage that the collector can be used as an air heat exchanger. If solar radiation is available and the collector is used as source for the HP, higher temperatures at the evaporator of the HP can be achieved than with a conventional air HP system.
\end{abstract}

Key words: Solar heat pump, solar system, heat pump, low energy buildings.

\section{Introduction}

In Austria and also in other European countries, several companies have developed solar air HP (heat pump) systems. In many of these systems, solar energy is not only used to charge a buffer storage (parallel system) but also as heat source for the evaporator of an HP. In some configurations, unglazed collectors are used as a heat source [1]. In the IEA SHC (International Energy Agency Solar Heating and Cooling Programme) Task 44 (www.iea-shc.org/task44), the performance and relevance of combined systems using solar thermal and heat pumps are evaluated, a common definition of the performance of such systems and contributions to a successful market penetration of this new promising combination of renewable technologies are provided [2]. In the task, more than 100 systems from participating countries were surveyed during 2010 and 2011. The results of the survey showed that $70 \%$ of systems were found to be parallel solutions, $7 \%$ serial

Corresponding author: Werner Lerch, Dipl.-Ing., research field: renewable energy. E-mail: werner.lerch@tugraz.at. systems, $21 \%$ complex systems and very few regenerative solutions. The number of air and ground source systems were about in the same range and some systems were operated only with solar collectors as source for the evaporator and many in several modes of operation [2].

\section{Solar Thermal and Heat Pump Systems}

In this paper, different heating systems are analyzed and compared through dynamic system simulations in TRNSYS (Transient System Simulation Program) [3]. On one hand, a conventional air HP system with and without solar thermal system with covered selectively coated collectors (parallel system) is considered in the project, and on the other hand, serial solar air HP systems with covered and uncovered selectively coated collectors have been defined and evaluated. Additionally, a system with ice storage has been taken into account.

\subsection{Concept 1}

Fig. 1 shows the hydraulic layout of Concept 1, which is an air HP system without any solar thermal 
system. The HP provides heat to the buffer storage but also directly to the heating system of the building. The buffer storage is divided into a DHW (domestic hot water) and an SH (space heating) volume. As a backup, an electrical heater is placed in the buffer storage (space heat volume), which provides heat at times when the performance of the HP is not sufficient to cover the heating demand. In this system without solar collectors, the buffer storage has a volume of $0.3 \mathrm{~m}^{3}$. The DHW preparation takes place through an external heat exchanger.

\subsection{Concept 2}

The difference between Concepts 1 and 2 is that, in Concept 2, a solar system is installed in a parallel way. For the solar system, glazed selectively coated collectors are used. The buffer storage volume is increased to $1 \mathrm{~m}^{3}$. In Fig. 2, the integration of the solar thermal system is shown. The solar loop is divided into a brine (solar side) and a water loop (buffer storage), whereby the heat transfer between them takes place via a plate heat exchanger (Fig. 2). Solar energy is only used to charge the buffer storage. As a second energy source, an air HP system is installed.

\subsection{Concept 3}

As shown in Fig. 3, Concept 3 is a serial solar HP system. As heat source for the HP, only unglazed selectively coated collectors are used. When the HP is operated, the unglazed collectors are used as heat source for the HP. Solar energy can either be used to charge the buffer storage or as heat source for the HP, a simultaneous operation is not possible.

\subsection{Concept 4}

Concept 4 is similar to Concept 3 with the difference of an additional ice storage (Fig. 4), which is used as source for the evaporator of the HP. As in Concept 3, unglazed selectively coated collectors are used. The buffer storage (hot water storage) is charged with priority. If the HP is operated and the solar thermal system supplies energy to the ice storage at the same time, then energy for the evaporator of the HP comes directly from the solar thermal system. The advantage is that in this case higher source temperatures can be achieved at the evaporator of the HP.

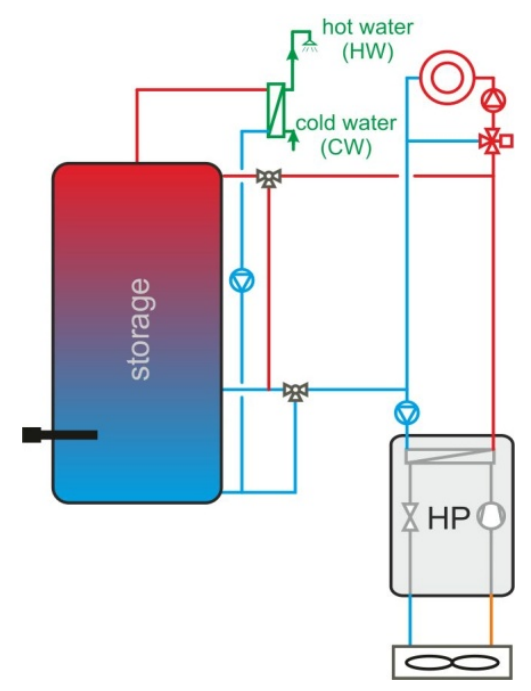

Fig. 1 Concept 1.

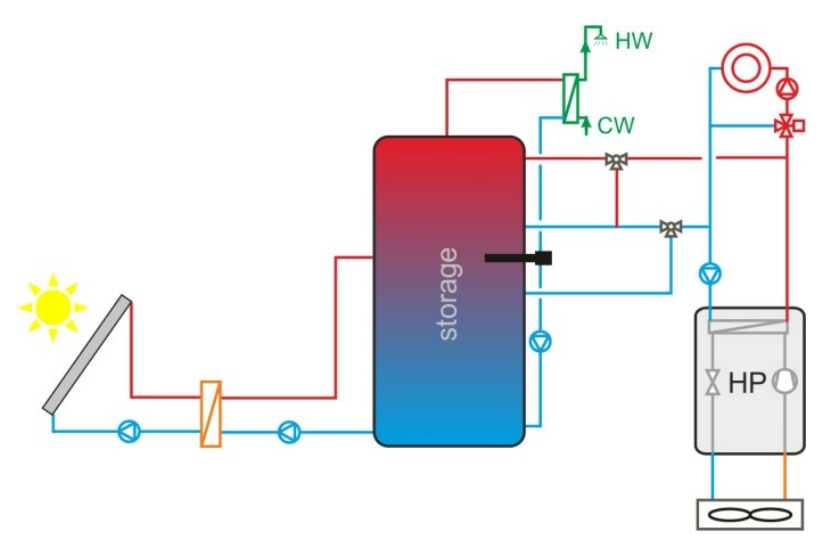

Fig. 2 Concept 2.

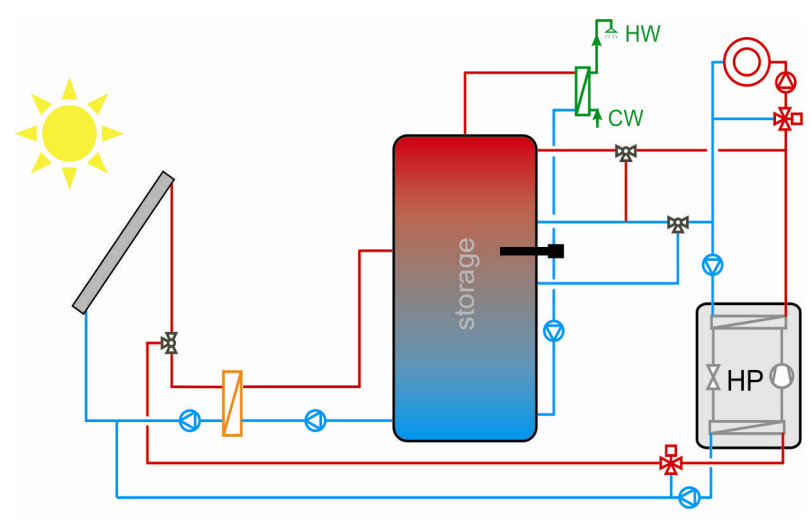

Fig. 3 Concept 3. 


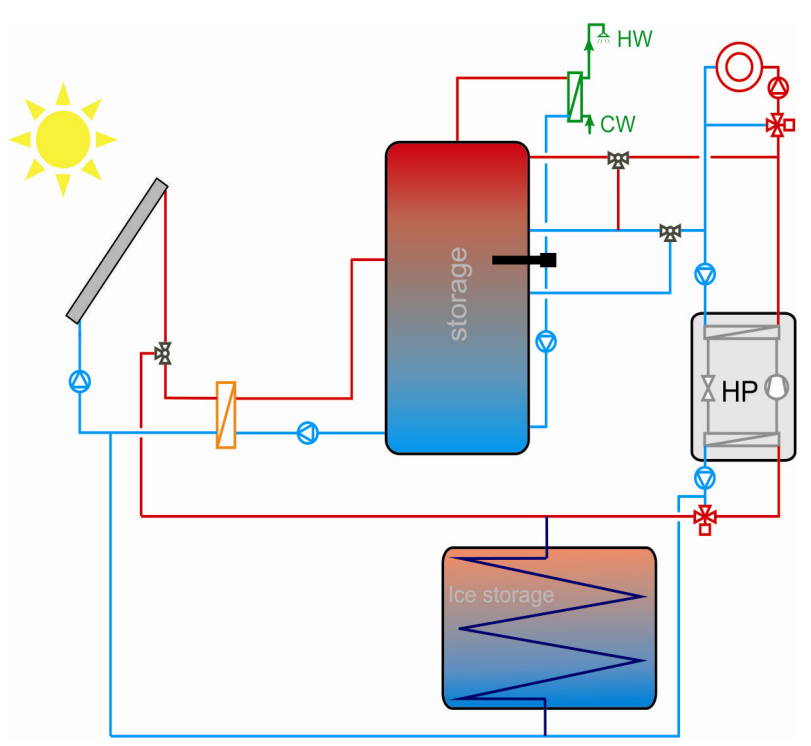

Fig. 4 Concept 4.

\section{Basic Conditions}

\subsection{Building}

For the system simulations, the boundary conditions of the IEA SHC Task 44 are used [4, 5]. In Task 44, three different buildings (single family house, heated floor area $140 \mathrm{~m}^{2}$ ) have been defined. For the climate in Strasbourg, the buildings have a specific heat demand of 15,45 and $100 \mathrm{kWh} / \mathrm{m}^{2} \mathrm{a}$ [5]. For SFH15 and SFH45, a floor heating system, and for SFH100, a radiator heating system is assumed. The flow temperature is controlled depending on the ambient air temperature (for SFH15 and SFH45, 35/30 ${ }^{\circ} \mathrm{C}$ at the design ambient temperature, radiator exponent 1.1 ; for SFH100, 55/45 ${ }^{\circ} \mathrm{C}$, radiator exponent 1.3 ).

The heat load of the building for the location Table 2 Used models in TRNSYS.
Strasbourg has been calculated for the design ambient temperature of $-12{ }^{\circ} \mathrm{C}$. For this calculation, the solar gains have not been considered, but the internal loads of the building, the present persons and the electronic equipment. With the heat preparation system, the heat demand of the building and the DHW demand shall be covered. For the dimensioning of the HP, the heat load of the building increased by $0.5 \mathrm{~kW}$ was used, which is to be covered by the HP at the operation point A2W35 (HP air source temperature $2{ }^{\circ} \mathrm{C}$ and water temperature on the sink side $35^{\circ} \mathrm{C}$ ). Table 1 shows the heat loads of the three buildings used.

\subsection{Domestic Hot Water}

The domestic hot water demand is used as defined in Task 44. The DHW preparation is done via a plate heat exchanger which is charged from the buffer storage in all systems. The hot water set temperature is defined as $45^{\circ} \mathrm{C}$. From the annual DHW heat demand, a mean daily heat demand of $5.85 \mathrm{kWh} / \mathrm{d}$ has been calculated.

\subsection{Simulation Models}

The dynamic system simulations have been performed using the software TRNSYS [1]. The most important component models (types) which were used in these simulations are listed in Table 2.

Table 1 Calculated heat loads of the considered buildings.

\begin{tabular}{llll}
\hline & SFH15 & SFH45 & SFH100 \\
\hline $\begin{array}{l}\text { Heat load }(\mathrm{kW}) \\
\begin{array}{l}\text { Heat load including DHW } \\
\text { preparation }(\mathrm{kW})\end{array}\end{array}$ & 2.53 & 4.86 & 8.68 \\
\hline
\end{tabular}

\begin{tabular}{|c|c|c|c|}
\hline Type number & Description & Documentation & Description/parameters \\
\hline Type 877 & Heat pump model & {$[6]$} & $\begin{array}{l}\text { Air HP, power: SFH15, } 3.03 \mathrm{~kW} \text {; SFH } 45,5.36 \mathrm{~kW} \text {; SFH100, } 9.18 \mathrm{~kW} \\
\text { (COP (coefficient of performance) at A2/W35 = 4.22) }\end{array}$ \\
\hline Type 832 & Collector model (glazed) & {$[7]$} & $\begin{array}{l}\text { Model glazed collector: } a_{1} \text { (linear heat loss coefficient) }=3.5 \mathrm{~W} /\left(\mathrm{m}^{2} \mathrm{~K}\right), a_{2} \\
\text { (quadratic heat loss coefficient) }=0.015 \mathrm{~W} /\left(\mathrm{m}^{2} \mathrm{~K}^{2}\right), \eta_{0} \text { (optical efficiency) } \\
=0.8\end{array}$ \\
\hline Type 203 & Collector model (unglazed) & {$[8]$} & $\begin{array}{l}\text { Model unglazed PVT (photovoltaic thermal) collector with } \\
\text { condensation: } a_{1}=9 \mathrm{~W} /\left(\mathrm{m}^{2} \mathrm{~K}\right), a_{2}=0 \mathrm{~W} /\left(\mathrm{m}^{2} \mathrm{~K}^{2}\right), \eta_{0}=0.954\end{array}$ \\
\hline Type 340 & Storage model & [9] & Buffer storage; volume: with solar $1 \mathrm{~m}^{3}$, without solar $0.3 \mathrm{~m}^{3}$ \\
\hline Type 843 & Ice storage model & {$[10]$} & $\begin{array}{l}\text { Ice storage: internal heat exchanger (pipe diameter } 20 \mathrm{~mm} \text {, distance } \\
\text { between pipes } 50 \mathrm{~mm}\end{array}$ \\
\hline Type 56 & Building model & {$[11]$} & Standard type; more zone model \\
\hline Type 362 & Radiator model & {$[12]$} & $\begin{array}{l}\text { SFH15 and SFH } 45 \text { : flow-/return flow temperature }=35 / 30{ }^{\circ} \mathrm{C} ; \mathrm{SFH} 100 \text { : } \\
\text { flow-/return flow temperature }=55 / 45^{\circ} \mathrm{C}\end{array}$ \\
\hline
\end{tabular}




\section{Evaluation Figures}

For the evaluation of the system performance, different indicators were defined. These indicators are the SPF (seasonal performance factor) of the system $\left(S P F_{\text {System }}\right)$, the seasonal performance factor of the HP $\left(S P F_{H P}\right)$ and the solar fraction $(S F)$.

The SPF of the entire system with penalties is defined as:

$$
S P F_{\text {System }}=\frac{\int\left(\dot{Q}_{S H}+\dot{Q}_{D H W}\right) \mathrm{d} t}{\int\left(P_{e l, t o t}+P_{e l, S H, p e n}+P_{e l, D H W, p e n}\right) \mathrm{d} t}(1)
$$

The definition of the SPF of the HP is:

$$
S P F_{H P}=\frac{\int \dot{Q}_{H P, C o n d} \mathrm{~d} t}{\int P_{e l, H P, t o t} \mathrm{~d} t}
$$

The Solar fraction as:

$$
S F=1-\frac{\int\left(\dot{Q}_{H P, \text { Cond }}+P_{\text {el, heater }}\right) \mathrm{d} t}{\int\left(\dot{Q}_{S H}+\dot{Q}_{D H W}\right) \mathrm{d} t}
$$

where:

$\dot{Q}_{S H}$ is the heat power space heat;

$\dot{Q}_{D H W}$ is the heat power domestic hot water;

$\dot{Q}_{H P, \text { Cond }}$ is the heat power HP condenser;

$P_{\text {el,tot }}$ is the electric power of all components (HP, controller, electric heater and all pumps);
$P_{e l, H P, t o t}$ is the electric power of entire HP (compressor, controller, fan of the outdoor unit);

$P_{e l, S H, p e n}$ is the electric power penalty space heating;

$P_{e l, D H W, p e n}$ is the electric power penalty DHW;

$P_{\text {el,heater }}$ is the electric power electrical heater.

\section{System Comparison}

Different systems evaluated using SFH45 are shown in Table 3.

\subsection{System Comparison}

The comparison of Concepts 1 and 2 shows that, by integration of a solar thermal system $\left(14 \mathrm{~m}^{2}\right)$, the $S P F_{\text {System }}$ for SFH45 can be increased from 2.92 to 3.84. The total electricity consumption of the system is reduced by about $23 \%$. The $S P F_{H P}$ is reduced, as the solar collectors are providing heat at times, when the HP would otherwise be operated with a high efficiency. However, $S P F_{\text {System }}$ is the more important figure from an overall system point of view.

The simulation results for Concepts 3 and 4 show that through the integration of an ice storage

\begin{tabular}{|c|c|c|c|c|c|c|c|c|c|}
\hline $\begin{array}{l}\text { Concept } \\
\text { different } \\
\text { performance } \\
\text { indicators. } \\
\text { Simulation } \\
\text { results for } \\
\end{array}$ & Building & $\begin{array}{l}\text { Collector area } \\
\left(\mathrm{m}^{2}\right)\end{array}$ & $\begin{array}{l}\text { Buffer storage } \\
\text { volume }\left(\mathrm{m}^{3}\right)\end{array}$ & $\begin{array}{l}\text { Ice storage } \\
\text { volume }\left(\mathrm{m}^{3}\right)\end{array}$ & $S P F_{\text {System }}$ & $S P F_{H P}$ & $S F(\%)$ & $\begin{array}{l}Q_{\text {el,tot }} \\
(\mathrm{kWh})\end{array}$ & $\begin{array}{l}Q_{\text {el, heater }} \\
(\mathrm{kWh})\end{array}$ \\
\hline 1 & \multirow{4}{*}{ SFH15 } & - & 0.3 & - & 2.44 & 3.27 & - & 1,832 & 97 \\
\hline 2 & & 14 & 1 & - & 3.64 & 2.80 & 37.2 & 1,234 & 130 \\
\hline 3 & & 30 & 1 & - & 3.35 & 3.25 & 22.5 & 1,340 & 180 \\
\hline 4 & & 30 & 1 & 1.2 & 3.38 & 3.38 & 21.6 & 1,328 & 187 \\
\hline 1 & \multirow{4}{*}{ SFH45 } & - & 0.3 & - & 2.92 & 3.57 & - & 2,861 & 133 \\
\hline 2 & & 14 & 1 & - & 3.84 & 3.32 & 24.8 & 2,194 & 152 \\
\hline 3 & & 30 & 1 & - & 3.54 & 3.56 & 15.2 & 2,383 & 278 \\
\hline 4 & & 30 & 1 & 1.2 & 3.49 & 3.68 & 13.2 & 2,420 & 305 \\
\hline 1 & \multirow{4}{*}{ SFH100 } & - & 0.3 & - & 2.71 & 3.13 & - & 5,881 & 244 \\
\hline 2 & & 14 & 1 & - & 3.31 & 3.04 & 14.3 & 4,835 & 187 \\
\hline 3 & & 30 & 1 & - & 3.06 & 3.07 & 7 & 5,224 & 272 \\
\hline 4 & & 30 & 1 & 1.2 & 2.93 & 3.19 & 4.8 & 5,545 & 584 \\
\hline
\end{tabular}
with the selected boundary conditions, the $S P F_{H P}$ can be

Table 3 Simulation results (Concepts 1-4). 


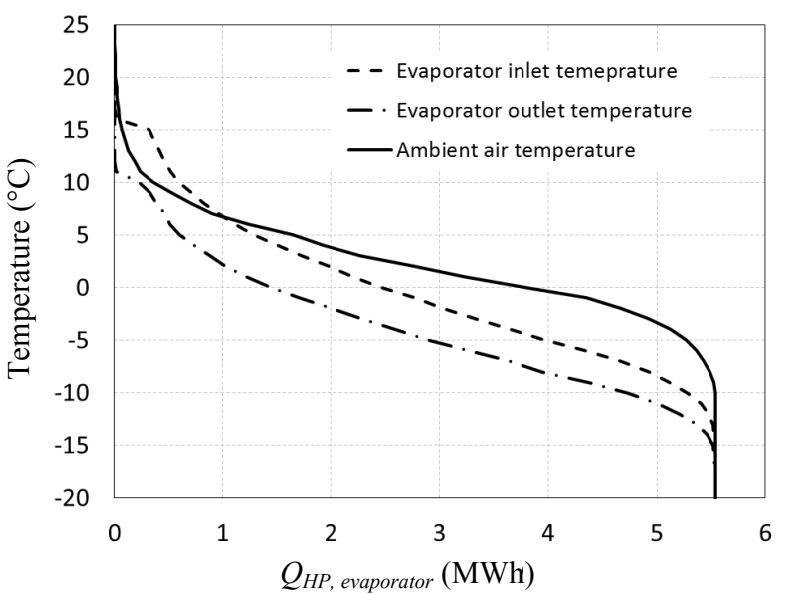

(a)

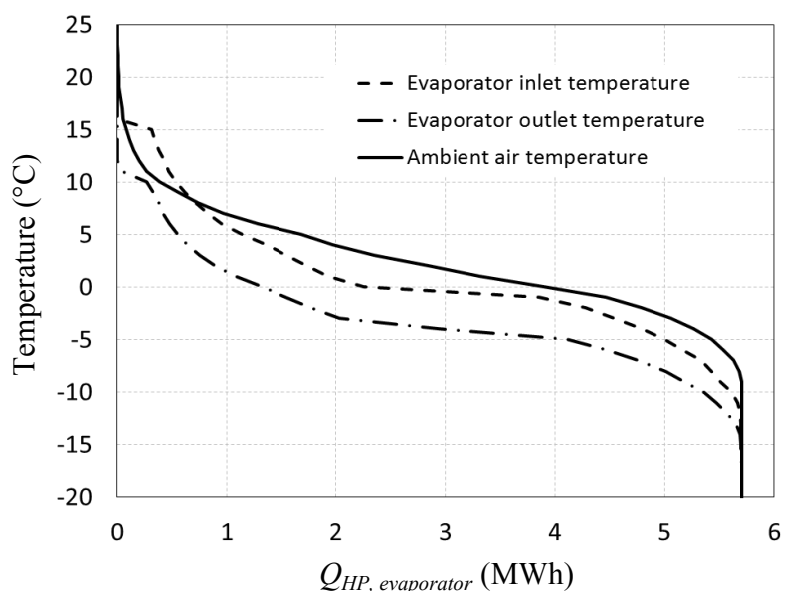

(b)

Fig. 5 Heat provided at the evaporator of the HP with different evaporator inlet- and outlet-temperatures for SFH45: (a) Concept 3, $30 \mathrm{~m}^{2}$ unglazed collector; (b) Concept 4, $30 \mathrm{~m}^{2}$ unglazed collector, $1.2 \mathrm{~m}^{3}$ ice storage.

increased, but the $S P F_{\text {System }}$ decreases. This is due to lower solar energy input directly to the buffer storage. For the SFH45 and for Concept 3, the solar fraction amounts $15.2 \%$ and for Concept 4 with an ice storage of about $1.2 \mathrm{~m}^{3}$ it is $13.2 \%$.

\subsection{Evaporator Inlet Temperature Compared to the Ambient Air Temperature}

Fig. 5 shows cumulative diagrams, in which the ambient air temperature and the evaporator inlet- and outlet temperature is shown as a function of the supplied heat at the evaporator of the HP. With Concept 3 (Fig. 5), 5,600 kWh is supplied by the unglazed collectors.

About $1,000 \mathrm{kWh}$ is provided to the evaporator with a brine inlet temperature higher than the ambient air temperature. This happens, when solar radiation is available, which lifts the brine temperature in the collector to a level higher than the ambient. With Concept 4 (Fig. 5b), 5,800 kWh is supplied by the unglazed collector and the ice storage of the solar system. The phase change (liquid/solid) in the ice storage can be clearly seen in the course of the evaporator inlet temperature. A comparison of Figs. $5 \mathrm{a}$ and $5 \mathrm{~b}$ shows that the integration of an ice storage causes an increase of the evaporator inlet temperature, which results in a higher efficiency of the HP $\left(S P F_{H P}\right)$. The heat pump efficiency $\left(S P F_{H P}\right)$ only increases slightly with the chosen boundary conditions (Concept 3: $S P F_{H P} 3.56$; Concept 4: $\left.S P F_{H P} 3.68\right)$.

\subsection{Monthly Simulation Results}

In Figs. 6 and 7, monthly heat balances for the SFH45 for Concepts 1-4 are shown. On the input side (Figs. 6a and 7a), the energy flows into the system and, on the output side (Figs. 6b and 7b), the energy demand of the system is shown. Additionally, average monthly performance figures are depicted $\left(S P F_{\text {System }}\right.$, $S P F_{H P}$ and solar fraction).

Fig. 6a shows the simulation results for the air HP system for SFH45. On the input side (Figs. 6 and 7) of the energy flow, the air source for the HP $\left(Q_{\text {air }}\right)$, the electricity consumption of the compressor of the HP $\left(W_{e l, c o m p, H P}\right)$ and the electricity consumption of the electrical heater $\left(W_{\text {el, heater }}\right)$ are shown. On the consumption side (Figs. $6 \mathrm{~b}$ and $7 \mathrm{~b}$ ), the energy for the DHW $\left(Q_{D H W}\right)$ and SH demand $\left(Q_{S H}\right)$ and also the heat losses of the storage $\left(Q_{\text {heatloss storage,HP}}\right)$, pipes ( $Q_{\text {heatloss }}$ pipes) and HP can be seen. The average monthly $S P F_{H P}$ decreases in the summer months because the HP is only in DHW mode. In the DHW mode, the temperature difference between heat source and sink is greater than in SH mode and, therefore in DHW mode, the HP is less efficient than in SH mode.

Fig. $6 \mathrm{~b}$ shows simulation results for the solar air HP system with $14 \mathrm{~m}^{2}$ glazed selective coated collectors 


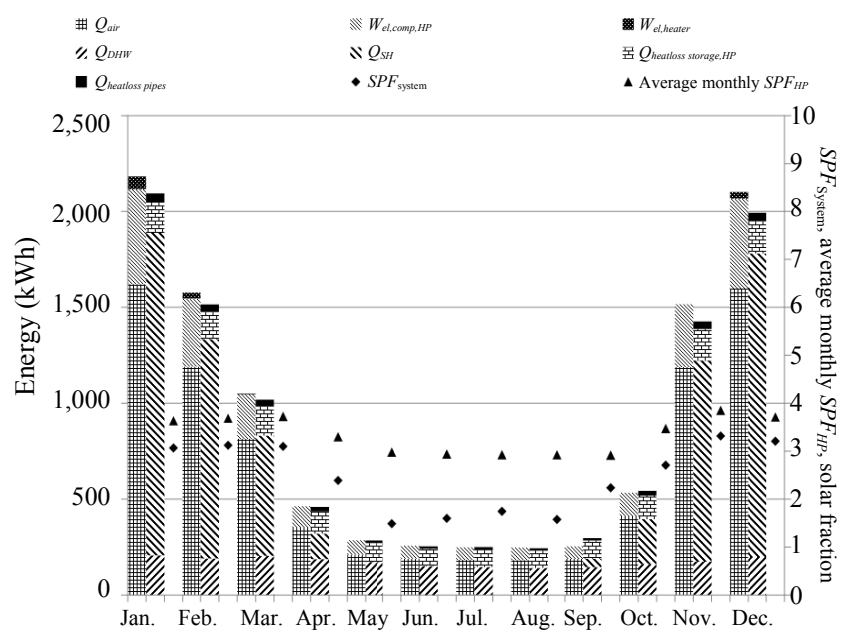

(a)

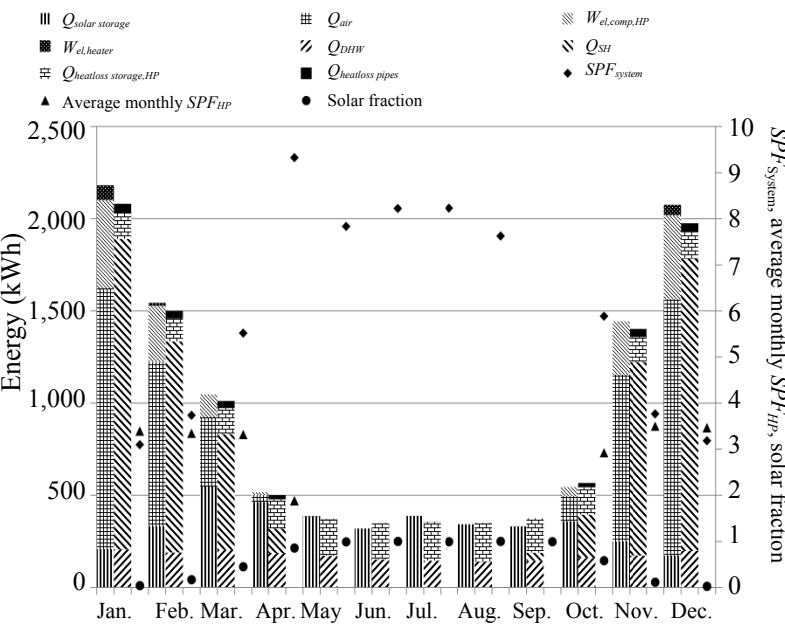

(b)

Fig. 6 Monthly heat balances SFH45: (a) Concept 1, air HP; (b) Concept 2, air HP and $14 \mathrm{~m}^{2}$ glazed selective coated collectors (parallel).

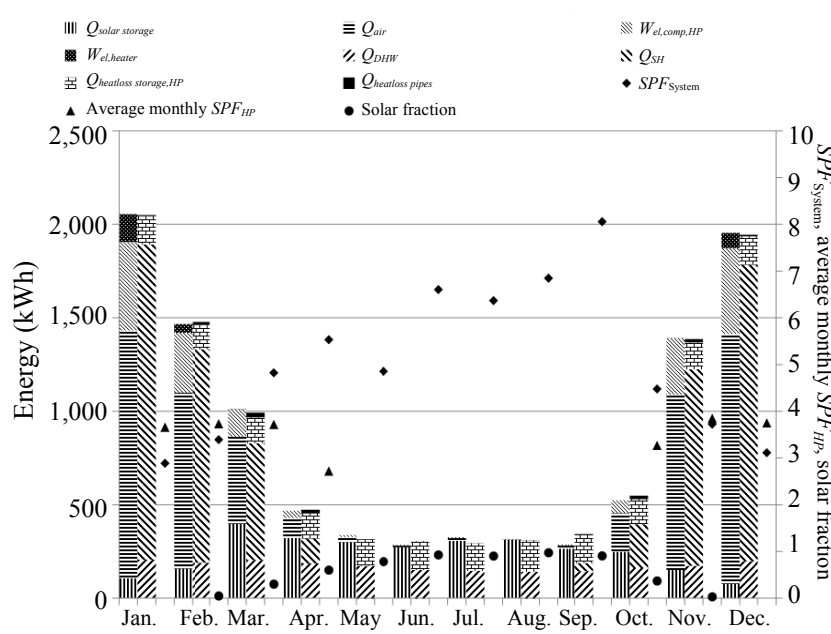

(a)

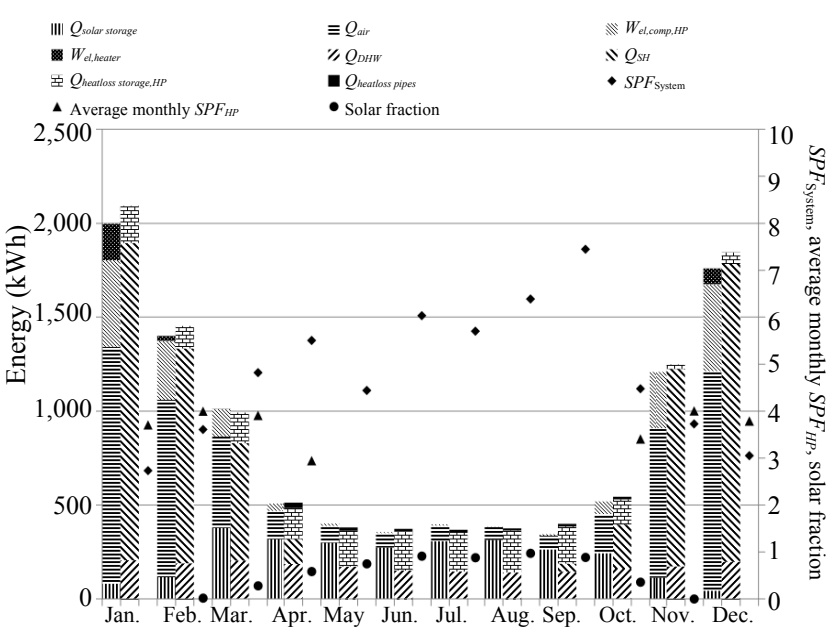

(b)

Fig. 7 Monthly heat balances SFH45: (a) Concept 3, HP and $30 \mathrm{~m}^{2}$ unglazed collector; (b) Concept 4, HP and $30 \mathrm{~m}^{2}$ unglazed collector, $1.2 \mathrm{~m}^{3}$ ice storage.

(parallel) for SFH45. Comparing the Figs. 6a and 6b, it can be observed that, through the integration of the solar thermal system, the system performance can be significantly increased. From May to September, the total heat demand can be covered through the solar thermal system.

In Fig. 7, the simulation results for the SFH45 for Concepts 3 and 4 are shown. In both figures (Figs. 6 and 7) on the input side, the solar energy, which is directly used to load the buffer storage, is shown in Figs. 6 and 7 as $Q_{\text {solar storage, and the solar energy which }}$ is used as heat source for the HP (or the ice storage) is shown in as $Q_{\text {solar } H P}$. In Concepts 3 and 4, the unglazed collectors are used as heat source for the HP. In Concept 4 , there is an additional ice storage. From May to September, the solar energy in Concept 3 is only used to charge the buffer storage, because the heat demand can be covered through the solar thermal system and there is no operating time of the HP. In Concept 4 , the solar energy is additionally used to charge the ice storage. In the summer months, there is also no operation time for the HP. 


\section{Conclusions}

Highly efficient combinations of solar thermal and heat pump systems (SolPumpEff) within this work, different combinations of solar energy and heat pump (HP) systems are analyzed through dynamic system simulations in TRNSYS. In such systems, solar thermal energy can be used, on the one hand, directly to charge a buffer storage and, on the other hand, as heat source for the evaporator of the HP. In this work systems, in which solar heat is only used directly (parallel operation of solar and HP), systems using the collectors also as a heat source for the HP are simulated and compared to conventional air HP systems. For the solar thermal system, glazed and unglazed selectively coated collectors have been considered. Using the latter type of collector as source for the HP offers the advantage that the collector can be used as an air heat exchanger.

With a combined parallel solar thermal HP system, the $S P F_{\text {System }}$ compared to a conventional HP system can be increased significantly. With unglazed selectively coated collectors as source of the HP, the evaporation temperatures of the HP can be increased compared to a conventional air HP system if solar radiation is available. With such collectors, a collector area of $15 \mathrm{~m}^{2}$ must be available to achieve the same $S P F_{\text {System }}$ than with a conventional air HP system with the used boundary conditions and assumptions.

\section{Acknowledgments}

This work was performed within the project "Highly Efficient Combinations of Solar Thermal and Heat Pump Systems (SolPumpEff)" and financed through the research and technology program "NeueEnergien 2020" by the Climate and Energy Fund in Austria.

\section{References}

[1] Bertram, E, Glembin, J, and Rockendorf, G. "Unglazed
PVT (Photovoltaic-Thermal) Collectors as Additional Heat Source in Heat Pump Systems with Borehole Heat Exchanger." Energy Procedia 30: 414-23.

[2] Hadorn, J. C. 2012. "IEA Solar and Heat Pump Systems, Solar Heating and Cooling Task 44 \& Heat Pump Programme Annex 38." Energy Procedia 30: 125-33.

[3] Solar Energy Lab, University of Wisconsin. 2012. TRNSYS 17. A Transient System Simulation Program: V17.01.0025. Madison: Solar Energy Lab, University of Wisconsin.

[4] Dott, R., Haller, M., Ruschenburg, J., Ochs, F., and Bony, J. 2011. Reference Buildings Description of the IEA SHC Task 11/HPP Annex 38. Subtask C-Working Group Boundary Conditions Draft, IEA SHC.

[5] Haller, M., Dott, R., Ruschenburg, J., Ochs, F., and Bony, J. 2011. The Reference Framework for System Simulations of the IEA SHC Task 44 / HPP Annex 38. A preliminary report of subtask $C$. Deliverable $C$ 1.3 Draft, IEA SHC.

[6] Heinz, A., and Haller, M. 2012. "Appendix A3-Description of TRNSYS Type 877 by IWT (Institute of Thermal Engineering) and SPF." In Models of Sub-components and Validation for the IEA SHC Task 44/HPP Annex 38-Part C: Heat Pump Models, edited by IEA SHC. A technical report of subtask C Deliverable C2.1 Part C.

[7] Haller, M., Paavilainen, J., Dalibard, A., and Perers, B. 2009. TRNSYS Type 832v3.07 Dynamic Collector Model by Bengt Perers. Updated Input-Output Reference. Graz: IWT.

[8] Stegman, M., and Bertram, E. 2011. "Model of an Unglazed Photovoltaic Thermal Collector Based on Standard Test Procedures." Presented at ISES (International Solar Energy Society)-Solar World Congress, Kassel.

[9] Drück, H. 2006. Multiport Store-Model for TRNSYS, Type 340 version $1.99 F$. Graz: IWT.

[10] Lerch, W., and Heinz, A. 2012. "Solar Thermal HP Systems Inkl. Waste Water Heat Recovery: Energy Assessment through Dynamic System Simulations in TRNSYS.” Presented at Gleisdorf Solar 2012, Gleisdorf. (in German)

[11] Transsolar Energietechnik GmbH. 2010. Type 56 Multizone Building Modelingwith Type 56 and TRNBuild. Stuttgard: Transsolar Energietechnik GmbH.

[12] Holst, S. 2010. Type 362 Dynamic Radiator Model with Pipes (Type 162). München: Bayrisches Zentrum für Angewandte Energieforschung e.V.. 